\title{
Brexit:
}

\section{England, Skotland og EU}

\section{Af Jørgen Ørstrøm Møller}

Brexit udgør et vandskel i europæisk og international politik. Der er ikke noget fortilfælde at støtte sig på. Politikerne står famlende. Økonomerne er enige om negative virkninger for Storbritannien, men ikke om størrelsesordenen og ej heller, hvordan det tidsmæssige forløb bliver - et kort chok eller en længerevarende udmarvning af den britiske økonomi. Mange og i nogle tilfælde modsatrettede tendenser og strømninger gør sig gældende.

I denne artikel vil søgelyset blive rettet mod fire aspekter:

- Er der tale om en global tendens; et opgør med eller måske endda et oprør mod økonomisk globalisering, som de fleste anså for uanfægtelig - en slags ensrettet vej.

- Kan Storbritannien holde sammen, eller vil Skotland og Nordirland bryde ud af denne statskonstruktion, der går tilbage til 1707 og derfor langtfra er så fasttømret, som de fleste forestiller sig.

- Hvad bliver virkningen på forholdet til EU i andre medlemslande, og hvorledes vil EU reagere på Brexit?
- Konsekvenserne for den globale verdensorden.

\section{Global tendens?}

Resultatet af Brexit afstemningen afspejler en reaktion fra en stor del af, hvad der kaldes 'den almindelige befolkning', som føler sig ladt i stikken, overset og tilsidesat eller måske endda undertrykt af eliten, der har lovet guld og grønne skove i kølvandet på den økonomiske globalisering, men vist sig ude af stand til at leve op til disse løfter.

Under sådanne omstændigheder vender mange mennesker sig mod politikere, der advokerer nationalisme, tilbagetagen af kontrol over egen skæbne og i store træk at vende det internationale samfund ryggen. Følelser, stemninger, instinktiv og intuitiv stillingtagen står over for logik, rationel tænkning, besindighed og overvejelser forud for en beslutning.

Brexit vil måske vise sig afgørende for, om denne tendens vinder fodfæste og breder sig over de kommende tiår eller løber ud i sandet. Kan et land klare sig godt, ja måske endda bedre, uden for et fasttømret internationalt samarbejde, er der

Jørgen Ørstrøm Møller, Visiting Senior Fellow, ISEAS Yusof Ishak I, Singapore, adjungeret professor ved Copenhagen Business School \& Singapore Management University, æresalumnus, Københavns Universitet og fhv. departementschef i Udenrigsministeriet. 
Remain: $80.0 \%-100.0 \%$

Remain: $72.5 \%-80.0 \%$

Remain: $67.5 \%-72.5 \%$

Remain: $62.5 \%-67.5 \%$

Remain: $60.0 \%-62.5 \%$

Remain: $57.5 \%-60.0 \%$

Remain: $55.0 \%-57.5 \%$

Remain: $52.5 \%-55.0 \%$

Remain: $50.0 \%-52.5 \%$

Leave: $50.0 \%-52.5 \%$

Leave: $52.5 \%-55.0 \%$

Leave: $55.0 \%-57.5 \%$

Leave: $57.5 \%-60.0 \%$

Leave: $60.0 \%-62.5 \%$

Leave: $62.5 \%-67.5 \%$

Leave: $67.5 \%-72.5 \%$

Leave: $72.5 \%-80.0 \%$

Leave: $80.0 \%$ - $100.0 \%$

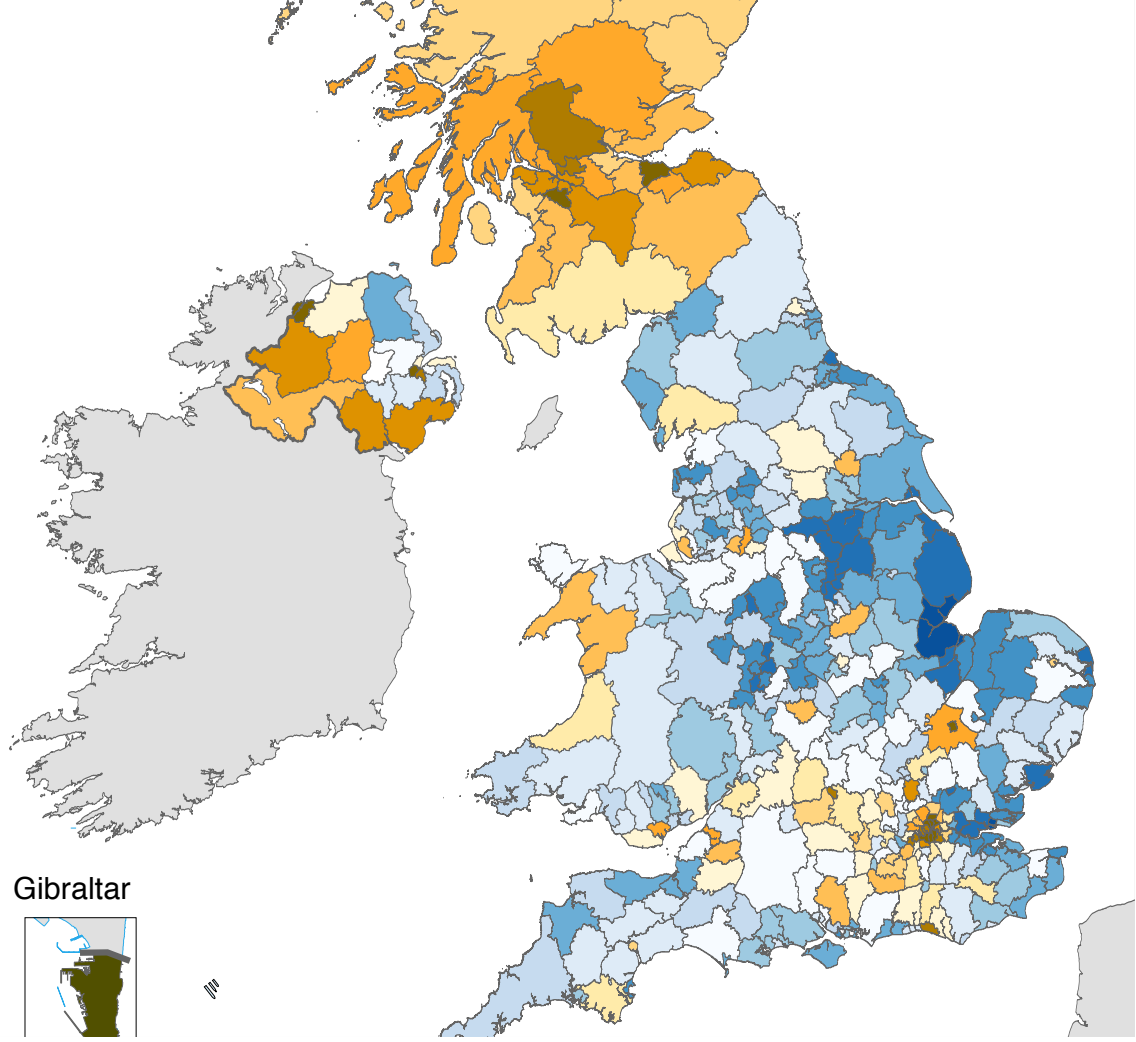

0

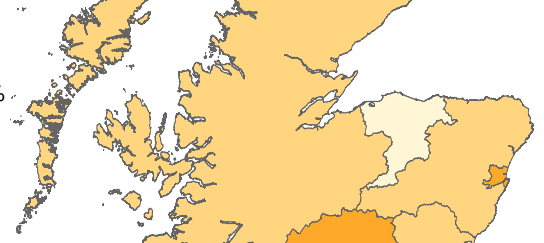

ILL.: Mirrorme22/Nilfarion via Wikimedia Commons

Resultatet af folkeafstemningen den 23. Juni 2016 on UK's fortsatte medlemskab af EU. 
sat et alvorligt spørgsmålstegn ikke alene ved EU's berettigelse, men ved hele det internationale - globale - system bygget op omkring et globalt retssamfund og global politisk kontrol, som modsvar til de økonomiske transaktioners spring fra det nationale til det globale niveau.

Ender Brexit derimod $\mathrm{i}$ håndgribelige og åbenbare negative konsekvenser for Storbritannien, med et politisk system ude af stand til at håndtere et sådant kvantespring, ledsaget af klare negative økonomiske virkninger, vil næppe mange andre lande føle sig fristet til at prøve det samme.

Den globale tendens med spørgsmålstegn ved globaliseringen har i mange år været synlig. Få tvivler på modellens evne til at levere højere økonomisk vækst end alternativer, som alle i højere grad fokuserer på en national økonomi.

\section{Større økonomisk ulighed}

Ifølge økonomisk teori er en politik velfærdsfremmende såfremt dem, der vinder, er i stand til at kompensere dem, der taber, og fortsat have en gevinst. Problemet er, at udviklingen igennem de seneste tiår afslører, at dem, der vinder, ikke kompenserer dem, der taber, men holder hele gevinsten for sig selv.

En analyse udarbejdet af Bloomberg og Credit Suisse i 2014 viser, at verdens 138 rigeste personer er i besiddelse af en formue af samme størrelsesorden som de 3,5 milliarder fattigste, dvs. 138 personer ejer lige så meget som den fattigste halvdel af jordens befolkning. Denne analyse suppleres af adskillige andre, som alle entydigt påpeger, at stort set hele stigningen i nationalindkomsten går til en meget lille del af befolkningen. I USA tilgår næsten seks pct. af nationalindkomsten mindre end 14.000 husholdninger. Fra 1980-1992 til 2008-2015 steg andelen af nationalindkomsten til den rigeste én pct. af befolkningen i USA fra 8 pct. til 18 pct., i Storbritannien fra 7 pct. til 12,5 pct. og i Danmark fra 5 pct. til 6,5 pct.

Ikke overraskende spørger en stor del af befolkningen sig selv, hvorfor de skal støtte og acceptere en model, der kanaliserer næsten 100 pct. af den årlige stigning i indkomsten til én procent af befolkningen - og det er et særdeles relevant spørgsmål. Hvorfor skal de det? De kunne måske have en bedre og højere levestandard med en lavere vækst, der fordeles mere ligeligt.

Den internationale handelsteori har i adskillige tiår holdt fast ved, at frihandel forøger den økonomiske vækst. Og det er fortsat ubestridt. To problemer rejser sig.

Det første er - igen - fordelingsproblemet. Frihandel fører til nedlæggelse af arbejdspladser i industrier, som mister toldbeskyttelse. Medmindre der gennemføres tiltag, som skaber arbejdspladser for dem, der mister deres job, placeres de i permanent arbejdsløshed helt uanset, om antal job i samfundsøkonomien stiger. Deres kompetencer er ikke tilstrækkelige til at sikre et job i de nye økonomiske sektorer. En skibsværftsarbejder kan ikke hoppe ind i informationsteknologi, bioteknologi eller finansielle tjenesteydelser.

Det andet er, at frihandel i det store og

Ender Вrexit derimod i håndgribelige og åbenbare negative konsekvenser for Storbritannien, med et politisk system ude af stand til at håndtere et sådant kvantespring, ledsaget af klare negative økonomiske virkninger, vil næppe mange andre lande føle sig fristet til at prøve det samme. 
hele er fuldt etableret, hvorfor mange nye initiativer, herunder TPP (Trans Pacific Partnership) mellem USA og en række lande i Stillehavsområdet og TTIP (Transatlantic Trade and Investment Partnership) mellem USA og EU, sigter på godkendelsesprocedurer, gensidig anerkendelse af kvalifikationer, afgørelser af tvister mv. Mange spørger sig selv, om de ikke er bedre tjent uden disse skridt.

\section{Den internationale finanskrise}

Eliten har i manges øjne svigtet ved at lade den globale finanskrise i 2008-2009 bryde ud i fuldt flor og derefter vise sig ude af stand til at fremkomme med løsninger.

De internationale institutioner, herunder navnlig Den Internationale Valutafond (IMF), har i stort set alle år siden 2009 startet med en prognose for vækst, der efterfølgende viste sig for høj og måtte revideres nedad. Det samme gælder de fleste nationale økonomi- og finansministerier. Det er forståeligt, at stillet over for et sådant jordskred svigter modellerne; men dem der lades i stikken er ligeglade med alle forklaringer, uanset hvor gode (eller dårlige) de end kan være. De drager den konklusion, at der er noget galt med modellen - den økonomiske globalisering.

Under Brexit-debatten svarede den britiske minister Michael Gove på en interviewers spørgsmål om hans reaktion på en stribe prognoser, der pegede på negative økonomiske konsekvenser af Brexit med ordene: "Folk her i landet er trætte af eksperter". Under et vælgermøde refererede en tilhænger af EU til fald i brut- tonationalproduktet i tilfælde af Storbritanniens udtræeden, men blev afbrudt af råb fra salen "det er dit forbandede (bloody) bruttonationalprodukt, ikke vores".

Misstemning og spørgsmålet om den $ø$ konomiske globalisering blev udtrykt i 2011 af den tidligere britiske handelsminister og medlem af Europa-Kommissionen Lord Mandelson med ordene "muligheder for mange, usikkerhed for de fleste”. De rammer meget præcist. De fleste mennesker udsættes for et kolossalt indtrykspres fra den omgivende verden, flygtninge og immigranter/gæstearbejdere bliver pludselig naboer, arbejdspladser flyttes til udlandet, og nationalstaten finder det vanskeligere at leve op til rollen som leverandør af basale sociale tjenesteydelser.

\section{Kontrollen tilbage}

I USA står Donald Trump og til en vis grad Hillary Clinton over for et vælgerkorps, der i det mindste delvist er grebet af skepsis eller direkte modstand over for globalisering. Brexit udtrykte det. Front National i Frankrig og tilsvarende politiske partier rundt omkring i Europa slår ind på en vej præget af afstandtagen over for det internationale samarbejde.

Brexit-debatten havde som sit slogan 'tag kontrollen tilbage'. Det vandt gehør og gik lige ind. For undertegnede kan det undre, at spørgsmålet om hvad sker der, hvis alle andre gør det samme, slet ikke kom på banen. Hvis alle tog kontrol tilbage, ville der ikke være noget internationalt samarbejde, intet internationalt retssystem, ingen internationale instituti-

Hvis alle tog kontrol tilbage, ville der ikke være noget internationalt samarbejde, intet internationalt retssystem, ingen internationale institutioner. I stedet ville verden være kastet ud i en kaoslignende situation. 
oner. I stedet ville verden være kastet ud i en kaoslignende situation.

Hvordan kan man forestille sig en sådan verden, eller snarere en ikke-verden, med vore dages teknologi, samhandel og internationale investeringer?

En del af svaret er elitens manglende evne og vilje til at tune ind på befolkningens bølgelængde. Fordelen ved globalisering - for eliten - forekommer så åbenlys, at etablerede politikere ikke finder det umagen værd at forstå de problemer, som en del af befolkningen stilles overfor.

Klarest kom det frem under den britiske valgkamp i 2010, da daværende premierminister Gordon Brown efter en meningsudveksling med en 65-årig vælger, der udtrykte misnøje med gæld og indvandring, var så uforsigtig - uvidende om at en mikrofon stadig var tilknyttet nettet - karakteriserede hende som blot 'den snæversynede kvinde'.

\section{Storbritannien eller England?}

Tre dage efter Brexit-afstemningen udtalte Skotlands førsteminister Nicola Sturgeon, at "det Storbritannien vi stemte for at forblive i (afstemningen i 2014 om Skotlands uafhængighed) eksisterer ikke længere".

Hermed er bolden givet op til et politisk drama, der meget vel kan ende med, at Storbritannien træder ud af EU; Skotland og Nordirland stemmer for at forlade Storbritannien, med Skotland som ansøger om medlemskab af EU og Nordirland på vej hen imod en forening med Irland.

For blot nogle måneder siden ville dette have været anset for fantasteri, men ikke længere. Lad os begynde med Nordirland.

Her stemte 56 pct. for at forblive i EU. Det har sine gode grunde. Efter fredsprocessen i 1998 blev grænsen mellem Nordirland og Irland åbnet, og dette skridt anses normalt som en betingelse for fortsat fred i denne hærgede del af det britiske rige. Med Storbritannien ude af EU bliver grænsen ikke alene Storbritanniens men EU's, og passage underkastes grænsekontrol - hvilket også bliver tilfældet for godstransport mv. Virkningen heraf for Nordirland bliver dramatisk, og det er svært at se, hvorledes der kan findes en løsning. Derfor er det mest sandsynlige, at Nordirland bevæger sig hen imod en afstemning om udtræden af Storbritannien.

Økonomisk er Nordirland i kraft af de økonomiske bånd til Irland tæt forbundet til EU. 61 pct. af dets eksport går til EU og 34 pct. til Irland. Nordirland har igennem årene bygget sig selv op som et velegnet sted for investeringer fra ikke-EU lande, der gennem produktion her får adgang til EU. Fredsprocessen har medvirket til at formindske den tilbageholdenhed, der tidligere gjorde sig gældende.

Afgørende for resultatet af en afstemning bliver dog næppe økonomiske forhold, men fordelingen på religioner. Den katolske del af befolkningen deler religion med Irland, men udgør et mindretal på ca. 40 pct.- dog steget fra ca. 30 pct. i 1970 'erne. De øvrige religioner er sammensat af flere grupper, normalt betegnet 'protestant unionists', med den fællesnævner, at de dels ikke er katolikker, dels ikke ønsker indlemmelse i Irland. I et forenet Irland bliver de et lille mindretal med frygt for flertallets magt.

Det springende punkt er, hvad 'protestant unionists' i den aktuelle situation vil vælge: Forbliven i Storbritannien med stor usikkerhed om fredsprocessens fremtid eller forening med Irland under ukendte omstændigheder.

Hvis fredsprocessen bryder sammen, kan det næppe påregnes, at Storbritannien har magt og vilje til på samme måde som tidligere at opretholde nogenlunde tåle- 
lige tilstande. Der er få indikationer, eftersom en debat herom ikke er begyndt endnu. Flertallet på 56 pct. for at blive i EU er nok en tvivlsom strømpil for stemmemønsteret ved en afstemning om forbliven eller ej i Storbritannien.

Undersøgelser om hvorledes befolkningen opfatter sin identitet, fordelt på nordirsk, britisk eller irsk, er heller ikke særlig hjælpsomme, idet en betydelig del angiver mere end ét tilhørsforhold. En mulighed, som givetvis kommer på banen, vil være et tilbud fra Irland om en form for garanti for mindretallets rettigheder.

\section{Skotland}

Hidtil har opmærksomheden været koncentreret om Skotland, men måske viser det sig, at Nordirland stemmer først. Bliver resultatet heraf løsrivelse fra Storbritannien, vil det være temmelig sikkert, at Skotland stemmer efterfølgende.

Skotland stemte med 62,5 pct. for at forblive i EU. Det er en meget klarere tilkendegivelse end England, hvor 53,4 pct. stemte for at træde ud.

I 2014 stemte skotterne om at blive i Storbritannien eller træde ud. Resultatet blev 55,3 pct. for at blive. Som Nicola Sturgeon udtrykte det, er forholdene nu anderledes, og der er i Skotland en debat om, hvorvidt en ny afstemning skal gennemføres. I følge SNP (Scottish National Party) er det ikke acceptabelt, at et flertal af engelske vælgere tager Skotland ud af EU.

Den nyudnævnte britiske premierminister Theresa Mays første skridt var at besøge Skotland og Nordirland i et forsøg på at holde sammen på riget. Det er noget usikkert, hvad der kom ud af dette, men besøgene afspejler den prioritet blandet med frygt, der findes i London for et slags mareridtsagtigt scenarium, hvor Nord- irland og Skotland sideløbende med forhandlinger mellem Storbritannien og EU forlanger en afstemning om uafhængighed. Det vil på det nærmeste efterlade Storbritannien handlingslammet.

Magtpolitisk har regeringen og parlamentet i London fat i den lange ende. Den skotske afstemning i 2014 skete med det britiske parlaments velsignelse. Teoretisk kunne det tænkes, at et nordirsk og skotsk ønske om afstemning afvises i London. I realiteten er det svært at se, hvorledes dette kan holde vand. I givet fald ville det britiske parlament, på et tidspunkt hvor der forhandles med EU som følge af en folkeafstemning, afvise Skotlands og/ eller Nordirlands ønske om en folkeafstemning.

Økonomisk set tegner der sig ikke et ensidigt gunstigt perspektiv for skotsk uafhængighed. Den skotske økonomi er ramt af den faldende oliepris, og Skotland er i højere grad end Nordirland afhængig af handel og investeringer med England.

Forud for afstemningen i 2014 førtes en til tider ophedet debat om, hvorvidt England overførte finansielle midler, dvs. 'subsidierede,' Skotland eller ej. Denne debat endte stort set uafgjort med uenighed og vanskeligt gennemskuelig finansiel statistik.

I august 2016 offentliggjorde førsteminister Nicola Sturgeon en analyse, der konkluderede, at Skotland uden for EU stod til at tabe et massivt beløb i nationalindkomst sammenlignet med fortsat medlemskab. Sådanne analyser er af gode grunde behæftet med usikkerhed, der gør dem til lette mål for kritik, og i det nævnte tilfælde blev den da også anklaget for ensidighed.

Det er derfor et ret sikkert gæt, at medens afstemningen i 2014 formentlig afgjordes af økonomiske overvejelser, vil en 
På sin vis kan det siges, at Brexit er et farvel til en slags tøvende integration og efterlader EU over for valget mellem enten disintegration med hensyn til såvel fælles politikker som antal medlemmer eller styrket og stærkere integration.

ny afstemning efter alt at dømme blive afgjort af andre - følelsesmæssige - hensyn.

På to områder kan Nordirlands og Skotlands beslutning få vital betydning: EU-integrationens fremtid og den internationale sikkerhedspolitik.

\section{Et stærkere eller svagere EU?}

Umiddelbart efter Brexit-afstemningen fremkom de politiske bevægelser og personer bag Brexit med næsten bombastiske udtalelser om en bølge af folkeafstemninger af tilsvarende karakter i de øvrige EU-lande. Danmark blev nævnt som et eksempel.

Det modsatte viste sig at være tilfældet. En stribe opinionsundersøgelser i Frankrig, Tyskland og Danmark gav det lidt overraskende resultat, at støtten til EU steg markant. Der kan være flere forklaringer på dette fænomen, og stemninger er ofte flygtige og skifter; men det synes som om befolkningen i EU-landene ikke har noget ønske om at følge i Storbritanniens fodspor.

De politiske ledere i kernen af EU, der nu klart tegner sig omkring Tyskland og Frankrig plus et par andre lande er indstillede på at styrke integrationen på tre vitale områder: Forsvar, herunder navnlig af militær karakter, valuta omkring euro som 'single currency', og flygtninge plus immigration.

De er nået til den konklusion, at deres, om man så må sige, skæbne står og falder med EU's evne til at levere løsninger på disse problemer. De erkender, at EU ikke har vist sig i stand hertil; men de er overbeviste om, at intet europæisk land kan klare det alene. For dem er det et spørgs- mål om overlevelse. Med andre ord: Den stik modsatte konklusion af den britiske.

Brexit er katalysator for at sætte stærkere europæisk integration i relief ved at fjerne det land som mere end nogen anden - tillige med Danmark - har sat foden på bremsen.

På sin vis kan det siges, at Brexit er et farvel til en slags tøvende integration og efterlader EU over for valget mellem enten disintegration med hensyn til såvel fælles politikker som antal medlemmer eller styrket og stærkere integration. Den europæiske kerne og den politiske elite har allerede givet deres svar: Stærkere og dybere integration.

De ser dette som den eneste mulighed for at undgå irrelevans i det politiske spil over for problemer af en art, som Europa ikke tidligere har stået overfor, og som kan udvikle sig til en eksistenskamp. Kan Europa klare de nye udfordringer med bibeholdelse af det værdigrundlag, som har båret Europa og den europæiske integration siden 1952?

Skotland og Nordirland sætter fingeren på et ømt punkt for flere EU-medlemmer: Deres status som nationalstater er anfægtet af folkeslag som mere eller mindre mod deres vilje holdes inden for denne ramme.

Lande som Spanien og til en vis grad Frankrig er i realiteten bygget omkring den største befolkningsgruppe, som udøver en form for kulturimperialisme over for andre grupper - som englænderne over for skotter og over for irere indtil 1921. Det har de affundet sig med, så længe nationalstaten udfyldte rollen som leverandør af serviceydelser, dvs. skabte 
Skotland og Nordirland sætter fingeren på et ømt punkt for flere EU-medlemmer: Deres status som nationalstater er anfægtet af folkeslag som mere eller mindre mod deres vilje holdes inden for denne ramme.

økonomisk, social og kulturel sikkerhed. Det er ikke længere tilfældet.

Catalonien i Spanien nævnes ofte som den region, der kan tænkes at følge efter. I det catalanske parlament er der flertal for uafhængighed. Opinionsundersøgelser giver et lidt flimrende billede. Sammenlignet med Skotland er den største hindring den spanske grundlov. Folkeafstemningen i Skotland fandt sted i overensstemmelse med det britiske parlament. Det er forfatningsmæssigt ikke muligt i Spanien. Denne forfatningsmæssige blokering fjerner imidlertid ikke det politiske problem.

Der gættes allerede på, om Spanien i tilfælde af skotsk uafhængighed efterfulgt af ansøgning om medlemskab af EU vil modsætte sig dette, som et signal om det umulige i at træde ud af en nationalstat og derefter ind i EU.

På lidt længere sigt er det mest sandsynligt, at Skotland er budbringer for en opløsning af Europa i hvad der kan betegnes som dets oprindelige bestanddele, forankret i regional kultur, som binder mennesker sammen i kraft af fælles værdinormer kombineret med en overbygning i form af et EU, der står for udenrigs-og sikkerhedspolitik, overordnet økonomisk politik plus andre politikker, der ikke kan klares på regionalt plan.

\section{Globale konsekvenser}

Skotlands løsrivelse fra Storbritannien kan blive startskuddet til ophøret af den globale styringsmekanisme, som sejrherrerne fra Anden Verdenskrig udformede i årene efter 1945, men som tiden for længst er løbet fra.

Storbritannien er et af de fem medlem- mer af FN's Sikkerhedsråd med vetoret. En skotsk uafhængighed 'reducerer' Storbritanniens tyngde og rejser umiddelbart spørgsmålet, om England uden videre kan overtage den rolle, som Storbritannien havde.

Da Sovjetunionen blev opløst i 1991, fik Den Russiske Føderation grønt lys fra de andre tidligere og nu selvstændige dele af Sovjetunionen til status som efterfølgerstat, og ingen andre anfægtede dette. Da det tidligere Jugoslavien faldt sammen i begyndelsen af 1990'erne, forsøgte Serbien det samme; men USA satte foden ned, og Serbien måtte træde ind i det internationale samarbejde som ny stat. Tjekkoslovakiets deling i 1992 førte til to nye stater, Tjekkiet og Slovakiet.

Skotland kan muligvis tiltræde, at England overtager Storbritanniens rolle; men det kan ikke på forhånd anses for givet, at andre medlemmer af FN indtager samme standpunkt. En reform af FN har længe kørt op og ned ad startbanen uden at komme i luften. En række lande føler givetvis at have større krav på permanent medlemskab af Sikkerhedsrådet end England.

Bag dette lurer et andet perspektiv. Uanset om det siges eller ej, spiller den britiske atomslagstyrke en rolle for landets status. Den består af fire atomdrevne undervandsbåde. De skal erstattes inden omkring år 2030, hvilket vil koste kolossale summer. Der er en stribe skøn mellem 45 milliarder pund sterling til over 200 milliarder. Det britiske forsvarsministerium har sagt 6 pct. af forsvarsbudgettet; men det er lidet vejledende, så længe dette budgets fremtidige størrelse ikke er kendt. 
Atomslagstyrken har baser i Skotland, og SNP har udtalt, at Skotland i tilfælde af uafhængighed ikke vil give England adgang til fortsat brug heraf. Opretholdes dette standpunkt, skal nye baser bygges samtidig med de nye ubåde, hvilket indebærer et voldsomt dræn på de britiske statsfinanser.

Det kan derfor tænkes, at Skotlands uafhængighed indebærer, at England ikke finansielt kan eller vil opretholde en atomslagstyrke. Parlamentet vedtog ganske vist med 472 stemmer mod 117 den 18 . juli 2016 forslag herom; men det skete på et tidspunkt, hvor pengene ikke var begyndt at rulle ud af kassen med krav om besparelser på andre og måske mere vælgerfølsomme dele af de offentlige udgifter.

En afvikling af atomslagstyrken vil formindske den håndgribelige militære slagkraft og have vidtrækkende politiske og psykologiske virkninger, herunder medvirke til, at Englands rolle som permanent medlem af Sikkerhedsrådet anfægtes.

For den atlantiske alliance vil et militært svagere - med eller uden atomslagstyrke - England have negative konsekvenser. Storbritannien var den uundværlige partner i NATO som brobygger mellem Nordamerika og det kontinentale Europa i kraft af geografisk placering, historisk rolle og hvad der kan betegnes slægtsskab med USA og Canada.

Et svagt England, rådvildt over for sin nye placering og uden 'overskud' til en formidlende rolle, vil ikke kunne dæmpe og udglatte efterhånden tydelige modsætninger mellem USA og de kontinentaleuropæiske lande. Frankrig og Tyskland stillede ikke op i 2003 til Irakkrig nummer to.

De europæiske lande deler ikke USA's syn på Kina som udfordrer til dets glo- bale førerposition - eller er måske ligeglade. Der er uenighed om forholdet til Rusland og Ukraine med nedsættende bemærkninger fra USA for et par år siden om europæernes rolle. TTIP ser ikke ud til at blive færdigforhandlet som følge af skepsis i Tyskland og Frankrig kombineret med stigende modstand i USA.

Et 'træt' USA, der for et par år siden gennemførte den såkaldte pivot til Asien og bliver mere og mere optaget af egne og indenrigspolitiske problemer, vil ikke have tilsvarende velvilje over for den atlantiske alliance som tidligere amerikanske præsidenter.

Præsident Obama og hans tidligere forsvarsminister Robert Gates har gjort det klart for europæerne, at de står overfor at skulle påtage sig byrden ved at forsvare sig selv. Truslen fra Rusland er ikke sammenlignelig med truslen i sin tid fra Sovjetunionen. Specielt er det vanskeligt at se nødvendigheden af amerikanske tropper i Europa som led i forsvaret af det amerikanske hjemland.

\section{Konklusion}

Brexit drejer sig ikke alene om Storbritanniens forhold til EU og EU's fremtid uden britisk medlemskab, men om Storbritannien som land kan holde sammen, og hvilken form det europæiske samarbejde antager over de næste tiår.

I global henseende bliver der fokus på, om tilslutningen til globaliseringen kan opretholdes kombineret med øget pres på det globale styringssystem i form af krav fra nye lande om større indflydelse på bekostning ikke alene af Storbritannien, men også andre europæiske lande og USA. 
